\section{Characterization and Identification of Spanish Olive Germplasm by Means of RAPD Markers}

\author{
A. Belaj ${ }^{1}$, I. Trujillo, D. Barranco, and L. Rallo \\ Departamento de Agronomía. ETSIAM. Universidad de Córdoba. Avenida \\ Ménendez Pídal s/n, Apdo 3048, 14080 Córdoba, Spain
}

Additional index words. cultivar identification, Olea europaea L., DNA fingerprinting

\begin{abstract}
Thirteen randomly amplified polymorphic DNA (RAPD) primers were assayed in 82 Spanish olive cultivars of economical interest. A total of 82 bands were scored giving an average of 6.3 bands per primer. A total of 4 (OPA-01) to 10 bands (OPA-19) was amplified, while the number of polymorphic fragments ranged from 2 (OPK-07) to 9 (OPA-19) with a mean of 5.7 polymorphic bands per primer. A total of $89 \%$ of the amplification products (73 bands) were polymorphic. The 13 primers yielded 184 banding patterns (14.9 per primer). The number of banding patterns per primer ranged from 4 (OPK-07) to 39 (OPA-19). Fifty-three unique banding patterns were found, the majority of them resulted from different combinations of polymorphic bands. The combination of only five primers OPA-19, OPF-06, OPX-01, OPX-03, and OPI-12, allowed identification of all the cultivars. Seventy-four cultivars $(90 \%)$ were identified only by the combination of the first four primers. The addition of the fifth primer (OPI-12) was necessary for the identification of the eight remaining cultivars $(10 \%)$. The ordination of the primers according to their practical discriminating capacity in this study was: OPA-19 > OPF-06 $>$ OPX-01 > OPX-03 > OPI-12. Hence RAPD markers are recommended for olive fingerprinting in order to generate a database for olive cultivar identification.
\end{abstract}

The olive is a characteristic plant of the Mediterranean basin. Its outstanding economical importance is mainly due to the use of the olive oil as the principal source of edible oil for the people of this area for millenia. Spain is the world's leading olive producing country. As occurs in other olive producing countries, the distinctive feature of olive plant material in Spain is the abundance of very old cultivars restricted to specific areas where they orignally grew (Barranco, 1997).

In an exploration survey of olive cultivars in Spain, carried out between 1972 and 1992,262 different cultivars were identified (Barranco and Rallo, 2000). These have been conserved in the World Olive Germplasm Bank of the CIFA "Alameda del Obsipo", Cordoba, Spain. The homonyms and synonyms have usually been troublesome in cultivar identification and management of olive genetic resources as names traditionally reflect common morphological traits (particularly of the fruit), place of origin or practical utility of the cultivars (Barranco and Rallo, 1984).

The high diversity of cultivars and the

Received for publication 29 July 2002. Accepted for publication 17 Mar. 2003. Contribution from the Dept. of Agronomy, Univ. of Cordoba, Cordoba, Spain. Thanks are due to Carmen del Río and the World Olive Germplasm Bank of the CIFA "Alameda del Obispo", Cordoba, for the facilities created. This research was funded by the INIA(Instituto Nacional de Investigación y Tecnología Agraria y Alimentaria del MAPA), Project CAO 98-001-C3-1 and by the European Union project (FAIR-CT95-0689). A.B. received a $\mathrm{PhD}$ grant from the Agencia Española de Cooperación Internacional (AECI), Spain.

${ }^{1}$ To whom reprint requests should be sent. E-mail: ag2belay@uco.es
Among them, outstanding productive cultivars such as 'Picual', 'Arbequina', 'Manzanilla de Sevilla', 'Empeltre', 'Blanqueta', 'Hojiblanca', 'Morisca', and 'Villalonga' (Barranco and Rallo, 2000) were included. Furthermore, the cultivars 'Picual' and 'Arbequina' have been used in an intraspecific breeding program carrried out by the Dept. of Agronomy at Cordoba Univ. Our objective was to describe the RAPD diversity among the Spanish olive cultivars, and to determine if RAPD markers can be used to accurately discriminate among the cultivars.

\section{Material and Methods}

Plant material and DNA extraction. Eighty-two Spanish olive cultivars from the World Germplasm Bank of the CIFA "Alameda del Obispo" in Cordoba, Spain, were studied (Table 1). These cultivars, chosen on the basis of their economical importance and geographical distribution (Barranco, 1997; Barranco and Rallo, 2000), were previously described by means of pomological characterization (Barranco and Trujillo, unpublished data). Genomic DNA was extracted from young leaf tissue collected in Spring 1999, following the method described by Belaj et al. (2001).

Polymerase chain reaction. Thirteen decamer oligonucleotides from kits A, F, I, $\mathrm{J}, \mathrm{K}, \mathrm{P}, \mathrm{Q}$, and $\mathrm{X}$ from Operon Technologies (Alameda, Calif.) were used for PCR amplifications. DNA was amplified in 20 $\mu \mathrm{L}$ reaction mixtures containing $20-40 \mathrm{ng}$ of template DNA, 0.05 U polymerase AmpliTaq DNA Stoffel fragment (Applied Biosystems, Foster City, Calif.), $0.75 \mathrm{~mm}$ each of dNTP (Roche, Basel, Switzerland), $20 \mu \mathrm{M}$ of the primer, $25 \mathrm{~mm} \mathrm{MgCl}_{2}, 50 \mathrm{~mm} \mathrm{KCl}$, and 10 mм Tris- $\mathrm{HCl}(\mathrm{pH} \mathrm{8.3)}$. The reactions were performed in a thermal cycler (GeneAmp PCR System 9600, Applied Biosystems) programmed for: 1 cycle of $1 \mathrm{~min}$ at $94{ }^{\circ} \mathrm{C}$ followed by 40 cycles: of $20 \mathrm{~s}$ at $94{ }^{\circ} \mathrm{C}, 20 \mathrm{~s}$ at $35^{\circ} \mathrm{C}$, and 2 min at $72{ }^{\circ} \mathrm{C}$, for denaturing, primer annealing, and extension, respectively. The last cycle was followed by incubation for $6 \mathrm{~min}$ at $72{ }^{\circ} \mathrm{C}$. All the reactions were conducted three times using DNA of different extractions and different lots of the AmpliTaq DNA polymerase.

Separation and visualisation of the amplification products. Amplification products were separated on polyacrylamide gels as they provide a higher resolution of the amplification fragments in comparison to agarose gels (Belaj etal., 2001). Gels of $18 \times 16 \mathrm{~cm}$ containing $10 \%$ acrylamide, $0.126 \%$ piperazine diacrylamide crosslinker in $0.375 \mathrm{M}$ Tris- $\mathrm{HCl}, \mathrm{pH} 8.8$, were separated in Tris glycine $(0.025 \mathrm{~m}$ Tris, and $0.192 \mathrm{~m}$ glycine) at $30 \mathrm{~mA}$ per gel for $3.5 \mathrm{~h}$. The DNA was visualized by silver staining as described by Bassam et al. (1991). Gels were photographed using a digital camera (Kodak DC 120, Eastman Kodak Co., Rochester, N.Y.). Molecular sizes of the amplification products were estimated using a 123-base pair (bp) DNA ladder from Sigma (St. Louis).

Data analysis. RAPD bands were scored as 1 (present) or 0 (absent) in a binary matrix 
Table 1. Cultivars analysed with their register number (RN) in the collection as well as the banding patterns obtained by the primers OPA-19, OPF-06, OPI-12, OPX-01, and OPX-03.

\begin{tabular}{|c|c|c|c|c|c|c|c|c|c|c|c|c|c|}
\hline Cultivar & $\mathrm{RN}$ & OPA-19 & OPF-06 & OPI-12 & OPX-01 & OPX-03 & Cultivar & $\mathrm{RN}$ & OPA-19 & OPF-06 & OPI-12 & OPX-01 & OPX-03 \\
\hline Alameño de Cabra & 285 & $\mathrm{~A}^{\mathrm{y}}$ & $\mathrm{A}$ & $\mathrm{A}$ & $\mathrm{A}$ & $\mathrm{A}$ & Lechín de Sevilla ${ }^{z}$ & 5 & $\mathrm{P}$ & $\mathrm{V}$ & $\mathrm{K}$ & G & $\mathrm{K}$ \\
\hline Alameño de Montilla & 39 & B & B & $\mathrm{B}$ & $\mathrm{B}$ & $\mathrm{B}$ & Limoncillo & 35 & $\mathrm{AB}$ & --- & I & A & A \\
\hline Alfafara ${ }^{z}$ & 605 & $\mathrm{C}$ & --- & $\mathrm{C}$ & A & A & Llumeta & 226 & $\mathrm{AG}$ & $\mathrm{U}$ & $\mathrm{L}$ & $\mathrm{v}$ & $\mathrm{P}$ \\
\hline Aloreña ${ }^{z}$ & 981 & $--x^{x}$ & $\mathrm{C}$ & $\mathrm{D}$ & A & $\mathrm{C}$ & Loaime & 414 & Q & --- & $\mathrm{D}$ & $\mathrm{E}$ & G \\
\hline Amargoso & 367 & $\mathrm{C}$ & $\mathrm{F}$ & $\mathrm{D}$ & --- & - & Lucio & 763 & $\mathrm{R}$ & $\mathrm{J}$ & $\mathrm{D}$ & A & $\mathrm{H}$ \\
\hline Arbequina $^{z}$ & 231 & $\mathrm{D}$ & $\mathrm{D}$ & $\mathrm{C}$ & $\mathrm{C}$ & $\mathrm{D}$ & Manzanilla Cacereña ${ }^{z}$ & 430 & A & --- & $\mathrm{E}$ & A & $\mathrm{H}$ \\
\hline Argudel & 1068 & $\mathrm{E}$ & - & $\mathrm{E}$ & $\mathrm{D}$ & $\mathrm{E}$ & Manzanilla del Centro & 499 & $\mathrm{~F}$ & --- & - & G & $\mathrm{H}$ \\
\hline Asnal & 437 & $\mathrm{AJ}$ & G & $\mathrm{L}$ & B & A & Manzanilla de Hellín & 801 & B & $\mathrm{K}$ & B & $\mathrm{E}$ & $\mathrm{H}$ \\
\hline Azul & 343 & $\mathrm{~F}$ & B & $\mathrm{F}$ & $\mathrm{E}$ & B & Manzanilla de Jaén & 56 & $\mathrm{~F}$ & $\mathrm{Y}$ & $\mathrm{B}$ & $\mathrm{G}$ & $\mathrm{H}$ \\
\hline Bical & 387 & $\mathrm{G}$ & $\mathrm{E}$ & $\mathrm{D}$ & A & A & Manzanilla de Montefrío & 401 & $\mathrm{AD}$ & $\mathrm{O}$ & A & $\mathrm{E}$ & $\mathrm{G}$ \\
\hline Blanquetav & 11 & $\mathrm{AF}$ & $\mathrm{F}$ & --- & B & $\mathrm{F}$ & Manzanilla de Sevilla ${ }^{z}$ & 21 & $\mathrm{~S}$ & $\mathrm{E}$ & A & B & A \\
\hline Bolvino & 46 & $\mathrm{AH}$ & Y & --- & $\mathrm{B}$ & $\mathrm{F}$ & Manzanilla del Piquito & 269 & $\mathrm{~T}$ & --- & M & $\mathrm{H}$ & $\mathrm{G}$ \\
\hline Buidiego & --- & --- & --- & $\mathrm{C}$ & $\mathrm{K}$ & $\mathrm{B}$ & Manzanilla Prieta & 360 & M & $\mathrm{B}$ & $\mathrm{L}$ & $\mathrm{E}$ & G \\
\hline Caballo & 333 & --- & $\mathrm{Z}$ & $\mathrm{D}$ & $\mathrm{J}$ & B & Menya & 1071 & $\mathrm{U}$ & $\mathrm{L}$ & $\mathrm{N}$ & $\mathrm{C}$ & --- \\
\hline Callosina & 40 & $\mathrm{O}$ & G & $\mathrm{C}$ & A & G & Mollar de Cieza & 612 & $\mathrm{C}$ & $\mathrm{K}$ & $\mathrm{D}$ & A & A \\
\hline Canetera & 653 & $\mathrm{Z}$ & $\mathrm{H}$ & $\mathrm{F}$ & $\mathrm{F}$ & $\mathrm{C}$ & Morisca $^{z}$ & 17 & V & G & B & $\mathrm{C}$ & A \\
\hline Cañivano Blanco & 52 & AL & I & A & G & B & Morona & 270 & $\mathrm{~N}$ & M & $\mathrm{F}$ & $\mathrm{E}$ & G \\
\hline Cañivano Negro & 259 & - & M & --- & $\mathrm{E}$ & B & Morrut $^{2}$ & 224 & $\mathrm{Y}$ & $\underset{\sim}{N}$ & $\mathrm{~F}$ & $\mathrm{E}$ & - \\
\hline Carrasqueño Alcaudete & 332 & $\mathrm{~F}$ & A & G & $\mathrm{E}$ & G & Negrillo de Estepa & 301 & A & $\tilde{\mathbf{N}}$ & A & $\mathrm{E}$ & - \\
\hline Castellana ${ }^{z}$ & 576 & $\mathrm{H}$ & I & --- & $\mathrm{E}$ & G & Nevado Basto & 305 & G & I & - & A & - \\
\hline Corbella & 645 & - & $\mathrm{O}$ & --- & A & $\mathrm{H}$ & Ocal & 282 & $\mathrm{~S}$ & $\mathrm{E}$ & A & $\mathrm{E}$ & G \\
\hline Cornezuelo de Jaén & 20 & I & B & $\mathrm{D}$ & B & $\mathrm{H}$ & Ojo de liebre & 413 & AI & B & $\mathrm{C}$ & A & A \\
\hline Cornicabra $^{z}$ & 10 & I & M & $\mathrm{H}$ & G & B & Palomar & 661 & $X$ & --- & $\mathrm{D}$ & $\mathrm{C}$ & $\mathrm{L}$ \\
\hline Curivell & 1072 & B & I & I & A & A & Pequeña de Casas Ibañez & 562 & --- & ---- & A & I & $\mathrm{E}$ \\
\hline Changlot Real ${ }^{\mathrm{z}}$ & 15 & G & B & $\mathrm{J}$ & $\mathrm{E}$ & G & Pico Limón & 273 & $\mathrm{AD}$ & $\mathrm{I}$ & G & A & A \\
\hline Chesna & 374 & -- & $\mathrm{O}$ & $\mathrm{J}$ & B & - & Picual $^{z}$ & 9 & $\mathrm{AB}$ & $\mathrm{P}$ & G & $\mathrm{E}$ & $\mathrm{A}$ \\
\hline Chorrúo & 290 & -- & G & $\mathrm{D}$ & A & $\mathrm{H}$ & Picual de Almería & 798 & $\mathrm{~T}$ & B & --- & G & A \\
\hline Empeltre $^{z}$ & 13 & $\mathrm{~J}$ & $\mathrm{C}$ & $\mathrm{D}$ & $\mathrm{E}$ & B & Picudo $^{z}$ & 3 & $\mathrm{AM}$ & --- & B & $\mathrm{E}$ & A \\
\hline Enaguas de Arenas & 586 & $\mathrm{C}$ & A & $\mathrm{J}$ & A & G & Picudo de Fruto Rojo & 316 & $\mathrm{AH}$ & $\mathrm{B}$ & $\mathrm{B}$ & B & - \\
\hline Farga $^{2}$ & 12 & --- & $\mathrm{C}$ & $\mathrm{F}$ & $\mathrm{E}$ & I & Rapasayo & 277 & $\mathrm{E}$ & Q & $\mathrm{D}$ & $\mathrm{E}$ & M \\
\hline Gatuno & 380 & --- & --- & A & $\mathrm{C}$ & - & Royal de Calatayud & 964 & $\mathrm{C}$ & $\mathrm{R}$ & $\mathrm{C}$ & $\mathrm{E}$ & I \\
\hline Genovesa & 970 & $\mathrm{~K}$ & A & $\mathrm{J}$ & $\mathrm{E}$ & $\mathrm{E}$ & Royal de Cazorla & 390 & $\mathrm{AC}$ & $\mathrm{AM}$ & $\mathrm{L}$ & $\mathrm{E}$ & $\mathrm{H}$ \\
\hline Gordal de Archidona & 755 & --- & --- & --- & B & G & Sevillenca $^{2}$ & 227 & $\mathrm{C}$ & $\mathrm{E}$ & D & $\mathrm{E}$ & G \\
\hline Gordal de Granada & 761 & $\mathrm{~L}$ & $\mathrm{~V}$ & $\mathrm{~K}$ & G & $\mathrm{H}$ & Vallesa & 613 & $\mathrm{AK}$ & $\mathrm{S}$ & $\mathrm{E}$ & $\mathrm{E}$ & $\mathrm{N}$ \\
\hline Gordal de Hellín & 804 & --- & A & $\mathrm{J}$ & A & B & Vera & 660 & --- & --- & $\mathrm{K}$ & A & --- \\
\hline Gordal Sevillana ${ }^{z}$ & 234 & $\mathrm{AM}$ & --- & $\mathrm{C}$ & G & $\mathrm{E}$ & Verdalón & 585 & $\mathrm{C}$ & B & $\mathrm{D}$ & A & A \\
\hline Gordalejo & 396 & $\mathrm{~F}$ & --- & --- & G & $\mathrm{D}$ & Verdial de Badajoz ${ }^{z}$ & 988 & $\mathrm{C}$ & A & I & A & G \\
\hline Hojiblanca $^{z}$ & 2 & $\mathrm{~B}$ & $\mathrm{~B}$ & $\mathrm{~K}$ & $\mathrm{E}$ & $\mathrm{B}$ & Verdial de Huevar² & 6 & $\mathrm{AE}$ & I & --- & G & $\mathrm{G}$ \\
\hline Imperial & 297 & M & G & $\mathrm{L}$ & $\mathrm{E}$ & $\mathrm{J}$ & Verdial Vélez Málagav & 883 & B & A & G & $\mathrm{E}$ & $\tilde{\mathbf{N}}$ \\
\hline Jabaluna & 392 & $\mathrm{~N}$ & $\mathrm{E}$ & $\mathrm{C}$ & $\mathrm{E}$ & $\mathrm{H}$ & Verdiell & 677 & AN & $\mathrm{S}$ & M & $\mathrm{E}$ & $\tilde{\mathbf{N}}$ \\
\hline Lechín de Granada $^{z}$ & 54 & $\tilde{\mathbf{N}}$ & A & G & $\mathrm{E}$ & A & Villalonga $^{2}$ & 364 & $\mathrm{AD}$ & $\mathrm{T}$ & --- & $\mathrm{E}$ & $\mathrm{O}$ \\
\hline
\end{tabular}

${ }^{\mathrm{z}}$ Major cultivars in Spain.

yThe capital letters represent the banding patterns for each primer.

${ }^{x}$ Missing data.

for each primer. A conservative criterion for the selection of bands was used. Only reproducible and well-defined bands in each of the three replications were considered as potential polymorphic markers. Banding patterns, i.e., the different combinations of bands obtained for each primer, were designated by the name of the respective primer followed by a capital letter (Table 1 and Fig. 1). The identification of olive cultivars was carried out by the combination of different primers.

\section{Results}

Genetic variability. A total of 82 bands were scored giving an average of 6.3 bands per primer. Four (OPA-01) to 10 bands (OPA19) were amplified when the 13 primers were used with the DNA of 82 Spanish cultivars (Table 2). The total number of monomorphic bands was $9(11 \%)$ with an average of 0.69 monomorphic bands per primer. The number of polymorphic fragments ranged from 2 (OPK-07) to 9 (OPA-19) with a mean of 5.7 polymorphic bands per primer. A total of $89 \%$ of the amplification products were polymor- phic (73 bands).

High variability in the frequency of polymorphic bands in the cultivars studied was observed. This frequency varied from 0.012 (bands present in only one cultivar of the 82 studied) to 0.988 (bands absent in only one cultivar of the 82 studied). In general, the average frequency of the above-mentioned bands was high (0.50).

The 13 primers yielded 184 banding patterns (14.9 per primer). The number of banding patterns per primer ranged from 4 (OPK-07) to 39 (OPA-19). Fifty-three unique banding patterns were found (Table 3 ), the majority of them resulted from different combinations of polymorphic bands found and a very few were obtained from the unique RAPD bands.

Cultivar identification with RAPD markers. The variability found with the 13 primers used made possible the identification of all the cultivars included in the study. The combination of five primers OPA-19, OPF-06, OPX-01, OPX-03, and OPI-12 allowed identification of all the cultivars (Table 1). Other combinations of primers could provide additional possibilities for identification of the cultivars.
The minimum number of necessary primers for the identification of each one of the varieties (considering only the five above-mentioned primers) is presented in Table 3.

Thirty-eight cultivars $(\approx 45 \%$ of the total) were discriminated with a single primer as a result of the presence of 53 unique patterns for these cultivars (Table 3). Twelve out of the 24 major Spanish olive cultivars (Table 1) are included in this group. Furthermore, the cultivars 'Menya', 'Pequeña de Casas Ibañez', 'Canetera', and 'Manzanilla del Piquito' were identified by unique patterns obtained by presence or absence of unique bands.

For the identification of the rest of the varieties the combination of banding patterns obtained by two or three primers was needed (Table 3). For instance, 40 cultivars $(48.7 \%$ of the genotypes) were discriminated by the combination of two primers. And the combination of patterns obtained by three primers was needed only for the identification of the four remaining cultivars $(6.3 \%)$.

Twenty-three cultivars with the same generic name were also included in this study such as 'Alameño' (2), 'Cañivano'(2), 'Gordal' 


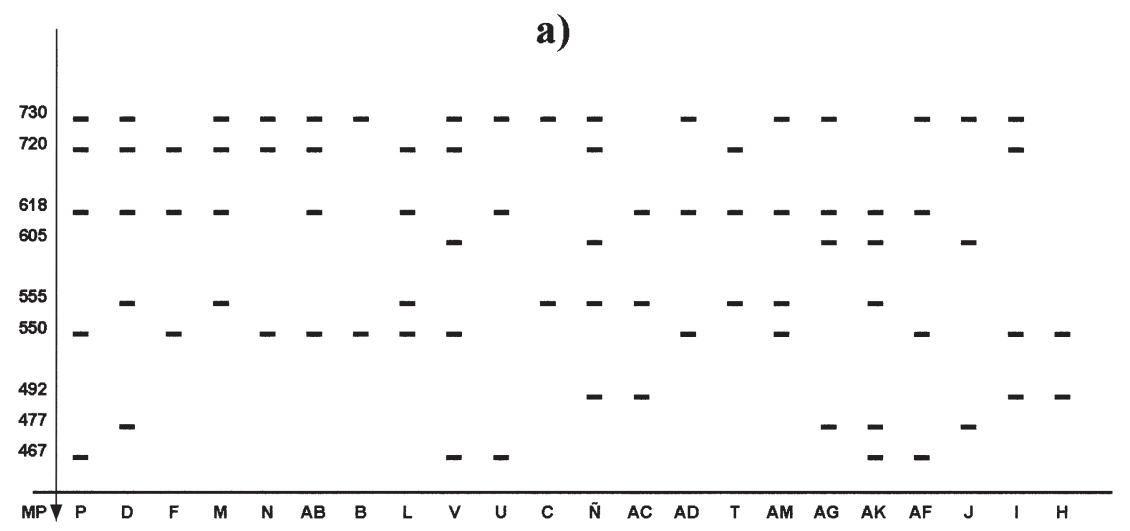

b)

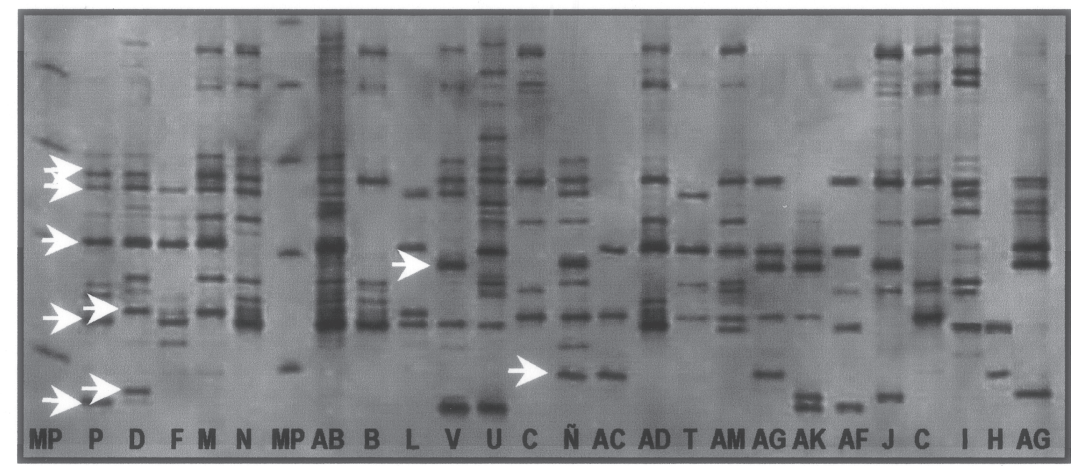

Fig. 1. PCR-RAPD products and schematic representation of some of the banding patterns obtained with the priner OPA-19 (a, b). the selected amplification products are indicated with arrows. The letters at the bottom of the photographs correspond to the banding patterns (b). The letters MP indicate the molecular marker. the molecular weight of the selected bands is indicated on the Y-axis (a).

(4), 'Lechín'(2) 'Manzanilla'(8), 'Picual' (2) and 'Verdial'(3) (Table1). These homonyms were clearly discriminated by means of RAPD markers.

The number of the cultivars discriminated by the cumulative power of the five primers was also calculated. In that way, twenty-three cultivars ( $28 \%$ of the cultivars studied) were discriminated using only the unique banding patterns obtained by the primer OPA-19 (Fig. 2). The percentage of the cultivars identi-

Table 2. Primers used, the total number of bands $(\mathrm{T})$, polymorphic bands $(\mathrm{P})$ and the number of banding patterns (BP) obtained for each primer.

\begin{tabular}{lrrr}
\hline Primer $^{2}$ & $\mathrm{~T}$ & $\mathrm{P}$ & $\mathrm{BP}$ \\
\hline OPA-01 & 4 & 4 & 6 \\
OPA-03 & 6 & 4 & 11 \\
OPA-19 & 10 & 9 & 39 \\
OPF-06 & 7 & 7 & 25 \\
OPI-12 & 6 & 5 & 13 \\
OPI-14 & 6 & 6 & 12 \\
OPJ-18 & 5 & 5 & 10 \\
OPK-07 & 5 & 2 & 4 \\
OPK-17 & 7 & 6 & 12 \\
OPP-19 & 6 & 6 & 13 \\
OPQ-15 & 6 & 6 & 14 \\
OPX-01 & 8 & 7 & 11 \\
OPX-03 & 6 & 6 & 17 \\
Total: 13 & 82 & 73 & 184 \\
\hline
\end{tabular}

Information about the fingerprinting data obtained by each primer can be obtained from the authors upon request. the identification of the 8 remaining varieties $(10 \%)$. The ordination of the primers according to their practical discriminating capacity in fied increased to $63.4 \%$ (a total of 52 cultivars) num the primer OPF-06 was added. And the $63(76.8 \%)$ and to $74(90 \%)$ respectively when a third (OPX-01) and a fourth (OPX-03) primer were further summed to the first two primers for the cultivar distinction. The addition of for the cultivar distinction. The addition of this study was: OPA-19> OPF-06 > OPX-01 $>$ OPX-03 > OPI-12.

\section{Discussion}

The olive tree (Olea europaea L.) is considered a highly heterozygous species, therefore the polymorphism found in this study is expected. The autochtonous origin and very low pressure of selection throughout history of olive cultivation have influenced to the high diversity of olive cultivars in Spain (Barranco and Rallo, 1984; 2000). In terms of identified polymorphisms, our results agree with previous studies obtained by means of RAPD markers in olive (Belaj et al., 2001; Besnard et al., 2001b; Sanz-Cortés et al., 2001). To our knowledge, this study is the most complete study of Spanish olive cultivars in terms of plant material and it also represents the first attempt to create a fingerprinting database by means of RAPD markers for these cultivars.

The identification of cultivars is a very important application of molecular markers in olive. Therefore the potential of RAPD markers to yield different banding patterns for as many cultivars as possible is of great interest. And selection of the most discriminating primers reduces the cost of analysis (i.e. the number of primers and thus the number of amplifications) for reliable cultivar distinction (Tessier et al., 1999).

The combination of only four primers (OPA-19, OPF-06, OPX-01, and OPX-03) made possible the distintion of $90 \%$ of the cultivars included in the study. The discrimination power of each primer depends not only on the number of banding patterns generated but also on their frequency. The last primer (OPI-12) was kept for its ability to discriminate the few nondistinguishable pairs of cultivars and not for its efficiency. Identification of the majority of the cultivars $(93.7 \%)$ by means of unique banding patterns or different combinations of the banding patterns provided by two primers is clear evidence of the high discrimination capacity of RAPD markers. However, discrimination of some of the most important

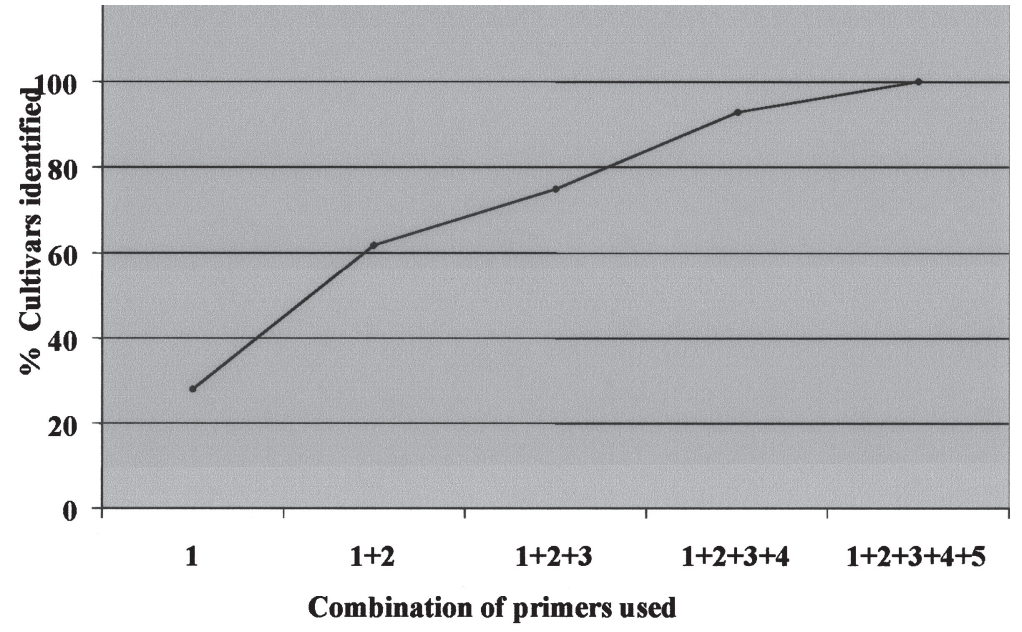

Fig. 2. Percentage ofthe cultivars discriminated by a certain number of primers comeination. $1=$ OPA-19; $1+2=$ OPA-19+OPF- $6 ; 1+2+3=$ OPA-19+OPF- $6+\mathrm{OPX}-01 ; 1+2+3+4=\mathrm{OPA}-19+\mathrm{OPF}-6+\mathrm{OPX}-01+\mathrm{OPX}-$ $03 ; 1+2+3+4+5=$ OPA-19+OPF-6+OPX-01+OPX-03+OPI-12. 
Spanish olive cultivars by cultivar-specific RAPD banding patterns provides the nursery industry with a powerfool tool to certify their plant material. Previous studies carried out in olive by means of RAPD markers have reported the utility of these markers for reliable identification of a relatively high number of cultivars using a small number of primers (Belaj et al., 2001; Besnard et al., 2001b; SanzCortés et al., 2001, Belaj, unpublished data). However, RAPDs present limitations when interpreting the results. The lack of reproduc- ibility of the technique requires the following of a well-stablished protocol for routine use in the laboratory as well as a conservative criteria at the selection of the amplification products (Belaj et al., 2001).

As in previous investigations carried out by means of morphological (Barranco, 1997; Barranco and Rallo, 1984) and DNA markers (Belaj et al., 2001; Mekuria et al., 1999; Wiesman et al., 1998), our results confirm the hypothesis that generic names such as 'Gordal', 'Lechín', 'Manzanilla', 'Verdial', etc., include different cultivars. No differences were found among the amplification profiles obtained from individuals trees of the same cultivar (data not shown). These results suggest the usefulness of different markers for an effective conservation and use of olive genetic resources in germplasm banks. Despite their great power of discrimination, molecular techniques should not be considered as substitutes of morphological characterization, but as complementary tools for the study of genetic resources (Karp et al., 1997).

Table 3. Identification of cultivars by a minimum number of primers.

\begin{tabular}{|c|c|c|c|}
\hline Cultivar name & Primer & Cultivar name & Primer \\
\hline \multicolumn{2}{|c|}{$\begin{array}{c}\text { Cultivars identified by } \\
\text { unique banding patterns (one primer) }\end{array}$} & \multirow[t]{2}{*}{ Cornezuelo de Jaen } & $\begin{array}{l}\text { OPA-19 (I) +OPF-06 (B); OPA-19 (I) + } \\
\text { OPX-01 (B); OPA-19 (I) + OPX-03 (H); }\end{array}$ \\
\hline Arbequina & OPA-19 (D); OPF-06(D) & & OPX-01 (B) + OPX-03 (H) \\
\hline Argudel & OPX-01(D) & \multirow[t]{3}{*}{ Curivell } & OPA-19 (B) +OPF-06 (I); OPA-19 (B) + OPX-01 \\
\hline Asnal & OPA-19 (AJ) & & (A); OPA-19 (B) + OPX-03 (A); OPF-06 (I) + \\
\hline Blanqueta & OPA-19 (AF); OPF-06 (F); OPX-03 (F) & & $\mathrm{OPX}-01(\mathrm{~A})$ \\
\hline Bolvino & OPF-06(Y) & \multirow[t]{3}{*}{ Enaguas de Arenas } & OPA-19 (C) +OPI-12 (J); OPF-06 (A) + OPI-12 \\
\hline Buidiego & OPX-01 (K) & & (J); OPI-12 (J) + OPX-01 (A); OPI-12 (J) + \\
\hline Caballo & OPF-06 (F) & & OPX-03 (G) \\
\hline Callosina & OPA-19 (O) & \multirow{2}{*}{ Farga } & OPF-06 (C) + OPX-03 (I); OPF-06 (C) + \\
\hline Canetera & OPA-19 (Z); OPX-01 (F); OPF-06 (H) & & OPI-12 (F) \\
\hline Cañivano Blanco & OPA-19 (AL) & Gordal de Archidona & OPX-01 (B) + OPX-03 (G) \\
\hline Castellana & OPA-19 (H) & Gordal de Hellín & OPF-06 (A) + OPX-03 (B) \\
\hline Cornicabra & OPI-12(H) & \multirow{2}{*}{ Gordal Sevillana } & OPA-19 (AM) + OPX-01 (G); OPA-19 (AM) \\
\hline Empeltre & OPA-19 (J) & & + OPX-03 (E): OPX-01 (G) + OPX-03 (E) \\
\hline Genovesa & OPA-19 (K) & Gordalejo & OPX-01 (G) + OPX-03 (D) \\
\hline Gordal de Granada & OPA-19 (L) & \multirow[t]{2}{*}{ Hojiblanca } & OPA-19 (B) +OPI-12 (K); OPI-12 (K) + \\
\hline Imperial & OPX-03 (J) & & OPX-01 (E); OPI-12 (K) + OPX-03 (B) \\
\hline Lechín de Granada & 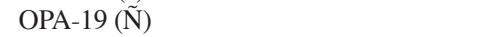 & \multirow[t]{2}{*}{ Jabaluna } & OPA-19 (N) +OPF-06 (E); OPA-19 (N) + \\
\hline Lechín de Sevilla & OPA-19 (P); OPX-03 (K) & & OPX-03 (H); \\
\hline Llumeta & OPA-19 (AG); OPF-06 (U); OPX-03 (P) & \multirow[t]{2}{*}{ Limoncillo } & OPA-19 (AB) + OPX-01 (A); OPA-19 (AB) \\
\hline Loaime & OPA-19 (Q) & & + OPI-12(I) \\
\hline Lucio & OPA-19 (R); OPF-06 (J) & \multirow[t]{2}{*}{ Manzanilla Cacereña } & OPA-19 (A) + OPX-03 (H); OPA-19 (A) + \\
\hline Manzanilla de Jaen & OPF-06 (Y) & & OPI-12 (E) \\
\hline Manazanilla del Piquito & OPX-01(H) & \multirow{2}{*}{$\begin{array}{l}\text { Manzanilla de Hellín } \\
(\mathrm{H}) \text {; }\end{array}$} & OPA-19 (B) +OPF-06 (K); OPA-19 (B) + OPX-03 \\
\hline Menya & OPA-19(U); OPF-06 (L); OPI-12 (N) & & \\
\hline Morisca & OPA-19 (V) & \multirow[t]{2}{*}{ Manzanilla de Sevilla } & OPA-19 (S) + OPX-01 (B); OPA-19 (S) + \\
\hline Morrut & OPF-06 $(\underset{\sim}{N})$ & & OPX-03 (A): OPX-01 (B) + OPX-03 (A) \\
\hline Negrillo de Estepa & 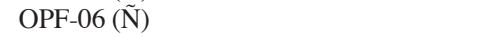 & \multirow[t]{2}{*}{ Manzanilla Prieta } & OPA-19 (M) +OPF-06 (B); OPA-19 (M) + \\
\hline Ojo de Liebre & OPA-19 (AI) & & OPX-03 (G); \\
\hline Palomar & OPA-19 (X); OPX-03 (L) & \multirow{2}{*}{$\begin{array}{l}\text { Mollar de Cieza } \\
\text { Morona }\end{array}$} & OPA-19 (C) +OPF-06 (K) \\
\hline Pequeña de Casas Ibañez & OPX-01 (I) & & OPA-19 (N) + OPF-06 (M) \\
\hline Picual & OPF-06 (P) & \multirow[t]{2}{*}{ Ocal } & OPA-19 (S) + OPX-01 (E); OPA-19 (S) + \\
\hline Rapasayo & OPF-06 (Q); OPX-03 (M) & & OPX-03 (G) \\
\hline Royal de Calatayud & OPF-06 (R) & \multirow[t]{2}{*}{ Pico Limón } & OPA-19 (AD) +OPF-06 (I); OPA-19 (AD) + \\
\hline Royal de Cazorla & OPA-19 (AC) & & OPX-03 (A) \\
\hline Vallesa & OPA-19 (AK); OPX-03 (N) & \multirow[t]{2}{*}{ Picual de Almeria } & OPA-19 (T) +OPF-06 (B); OPA-19 (T) + \\
\hline Verdial de Huevar & OPA-19 (AE) & & OPX-01 (G); OPA-19 (T) + OPX-03 (A); \\
\hline Verdiell & OPA-19 (AN) & \multirow[t]{2}{*}{ Picudo } & OPA-19 (AM) + OPX-01 (E); OPA-19 (AM) \\
\hline Villalonga & OPF-06 (T); OPX-03 (O) & & + OPX-03 (A) \\
\hline \multirow[t]{2}{*}{ Total } & 38 cultivars & Picudo de Fruto Rojo & OPA-19 (AH) + OPF-06 (B) \\
\hline & Cultivars identified by the & Sevillenca & OPA-19 (C) + OPF-06 (E) \\
\hline bandin & $g$ patterns obtained by two primers & Vera & OPI-12 (K) + OPX-01 (A) \\
\hline Alameño de Cabra & $\begin{array}{l}\text { OPA-19 (A) +OPF-06 (A); OPA-19 (A) + } \\
\quad \text { OPX-03 (A) }\end{array}$ & Verdalón & $\begin{array}{l}\text { OPA-19 (C) + OPF-06 (B); OPF-06 (B) + } \\
\text { OPX-01 (A) }\end{array}$ \\
\hline Alameño de Montilla & $\begin{array}{l}\text { OPA-19 (B) + OPX-01 (B); OPX-01 (B) + } \\
\text { OPX-03 (B) }\end{array}$ & Verdial de Badajoz & $\begin{array}{l}\text { OPA-19 (C) +OPI-12 (I); OPF-06 (A) + } \\
\text { OPI-12 (I); OPI-12 (I) + OPX-01 (A); }\end{array}$ \\
\hline Aloreña & OPX-01 (A) + OPX-03 (C) & Verdial Velez Malaos & $\begin{array}{l}\text { OPI-12 (I) + OPX-03 (G) } \\
\text { OPA-19(B)+OPF-06 (A) } \cdot \text { PPA-19(B)+ }\end{array}$ \\
\hline Azul & $\begin{array}{l}\text { OPA-19 (F) +OPF-06 (B); OPA-19 (F) + } \\
\text { OPX-03 (B) }\end{array}$ & verdial velez Mialagc & 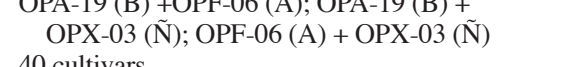 \\
\hline Bical & OPA-19 (G) +OPF-06 (E); OPA-19 (G) + & Total & 40 cultivars \\
\hline & OPX-03 (B); OPF-06 (E) + OPX-01 (A) & & Cultivars identified by the \\
\hline Carrasqueño Alcaudete & OPA-19 (F) +OPF-06 (A); OPA-19 (F) + & ban & patterns obtained by three primer \\
\hline & OPX-03 (G) & Alfafara & OPA-19 (A) + OPI-12 (I) + OPX-01 (A); \\
\hline Changlot Real & OPA-19 (G) +OPF-06 (B); OPA-19 (G) + & & OPA-19 (A) + OPX-03 (A) + OPX-01 (A) \\
\hline & OPX-01 (E); OPA-19 (G) + OPX-03 (G) & Amargoso & OPA-19 (K) + OPF-06 (F) + OPI-12 (D) \\
\hline Chesna & OPF-06 (O) + OPX-01 (B) & Cañivano Negro & OPF-06 (M) + OPX-01 (E) + OPX-03 (B) \\
\hline Chorruo & OPF-06 (G) + OPX-03 (H) & Manzanilla del Centro & OPA-19 (F) + OPX-01 (H) + OPX-03 (G) \\
\hline Corbella & $\begin{array}{l}\text { OPF-06 (O) + OPX-01 (A); OPF-06 (E) + } \\
\text { OPX-03 (H) }\end{array}$ & Total & 4 cultivars \\
\hline
\end{tabular}


The development in this research of RAPD markers/fingerprints of the main and industrially important olive cultivars from Spain may help for generating a molecular database to reliably catalogue the cultivars. The utilization of this information in a systematic way will facilitate the management of cultivar collections and control the trade of plant material. In order to complete and refine the RAPD data obtained in this study, further studies with larger olive samples and other types of molecular markers, which can permit the interchange of data between different scientific groups and laboratories, SSRs, (de la Rosa et al., 2002; Rallo et al., 2000) are needed. SSRs are currently being used for the characterization and identification of the Germplasm Bank of Cordoba.

\section{Literature Cited}

Barranco, D. 1997. Variedades y patrones. p. 59-80. In: D. Barranco, R. Fernández-Escobar, and L. Rallo (eds.). El cultivo del olivo. Mundiprensa y Junta de Andalucía, Madrid, Spain.

Barranco, D. and L. Rallo. 1984. Las variedades de olivo cultivadas en Andalucía. M. ${ }^{\circ}$ de Agricultura, Junta de Andalucía, Madrid, Spain.

Barranco, D. and L. Rallo. 2000. Olive cultivars in Spain. HortTechnology 10:107-110.

Barranco, D., A. Cimato, P. Fiorino, L. Rallo, A.
Touzani, C. Castañeda, F. Serafín, and I. Trujillo. 2000. World catalogue of olive varieties. Int. Olive Oil Council. Madrid, Spain.

Bassam, B.J., G. Caetano-Anollés, and P.M. Gresshoff. 1991. Fast and sensitive silver staining of DNA in polyacrylamide gels. Anal. Biochem. 80:81-84.

Belaj, A., I. Trujillo, R. de la Rosa, L. Rallo, and M.J. Giménez. 2001. Polymorphism and discriminating capacity of randomly amplified polymorphic markers in an olive germplasm bank. J. Am. Soc. Hort. Sci. 126:64-71.

Besnard, G., P Baradat, and A. Bervillé. 2001a. Genetic relationships in the olive (Olea europaea $L$.) reflect multilocal selection of cultivars. Theor. Appl. Genet. 102:251-258.

Besnard, G., C. Breton, P. Baradat, B. Khadari, and A. Bervillé. 2001b. Cultivar identification in olive based on RAPD markers. J. Am. Soc. Hort. Sci. 126:668-675.

De la Rosa, R., C. James, and K.R. Tobutt. 2002. Isolation and characterization of polymorphic microsatellite in olive (Olea europaea L.) and their transferability to other genera in the Oleacea. Primer note. Mol. Ecol. Notes. 2:265-267.

Fabbri, A., J.I. Hormaza, and V.S. Polito. 1995. Random amplified polymorphic DNA analysis of olive (Olea europaea L.) cultivars. J. Amer. Soc. Hort. Sci. 120:538-542.

Karp, A., S. Kresovich, K.V. Bhat, W.G. Ayad, and T. Hodgkin. 1997. Molecular tools in plant genetic resources conservation: A guide to the technologies. IPGRITech. Bul. No. 2. Intl. Plant Genetic Res. Inst., Rome.

Mekuria, G.T., G.G. Collins, and M. Sedgley. 1999. Genetic variability between different accessions of some common commercial olive cultivars. J. Hort. Sci. Biotechnol. 74:309-314.

Rallo, P., G. Dorado, and A. Martin. 2000: Development of simple sequence repeats (SSRs) in olive tree (Olea europaea L.). Theor. Appl. Genet. 101:984-989.

Sanz-Cortés, F., M.L. Badenes, S. Paz, A. Iñiguez, and G. Llácer. 2001. Molecular characterization of olive cultivars using RAPD markers. J. Am. Soc. Hort. Sci. 126:7-12.

Tessier, C., J. David, P. This, J.M. Boursiquot, and A. Charrier. 1999. Optimization of the choice of molecular markers for varietal identification in Vitis vinifera L. Theor. Appl. Genet. 98:171-177.

Trujillo, I., L. Rallo, and P. Arus. 1995. Identifying olive cultivars by isozyme analysis. J. Amer. Soc. Hort. Sci. 120:318-324.

Wiesman, Z., N. Avidan, S. Lavee, and B. Quebedeaux. 1998. Molecular characterization of common olive varieties in Israel and the West bank using randomly amplified polymorphic DNA (RAPD) markers. J. Amer. Soc. Hort. Sci. 123:837-841.

Williams, J.K., A.R. Kubelik, K.J. Livak, J.A. Rafalski, and S.V. Tingey. 1990. DNA polymorphisms amplified by arbitrary primers are useful as genetic markers. Nucleic Acids Res. 18:6531-6535. 